\title{
Polar Wander and/or Plate Tectonics in the Palaeozoic
}

\author{
(Report of a Geophysical Discussion held on 1970 October 9)
}

Professor K.M.Creer (Newcastle) who arranged this meeting, took the Chair at 2 p.m. In formal contributions, Professor Creer and Dr J.C.Briden (Leeds) discussed the relevant evidence from palaeomagnetism; Professor S.K.Runcorn (Newcastle) discussed how polar wander and continental drift might be attributed to different kinds of convective motion in the mantle; Professor J.Sutton (Imperial College), Dr F.Vine (East Anglia) and Mr B.J.Harland (Cambridge) spoke of various types of geological evidence, particularly of a structural and petrological nature.

The concept of sea-floor spreading, which led to the now widely accepted model of a crust formed of thin rigid plates being pushed apart along some boundaries and against one another along other boundaries, has removed many of the objections to Wegener's hypothesis of a Mesozoic and Tertiary phase of continental drift. So, if we follow Lyell's principle of uniformitarianism, it would seem reasonable to extend the plate model to older geological periods, and as a first step ask ourselves whether there are any evidences of ancient plate boundaries in the Palaeozoic crust and of movements between these plates. The discussion was thus essentially about whether sea-floor spreading and plate movements have been recurring features of crustal development throughout geological time, and if so whether they can completely account for the observed crustal features.

Professor Creer showed that Middle and Upper Palaeozoic palaeomagnetic data computed for suitably long time intervals for the different continents indicated a number of relatively rapid apparent polar shifts. He argued that, when these poles were plotted on a globe bearing the geography of a single landmass-Pangea-rather than against the present global geography, then three of these apparent polar shifts coincided in direction and also, it appeared, in timing (within the time limits that can be attached to them at present). Hence he thought that they might be evidence of real polar wander, i.e. of movement of the body of the whole earth relative to the angular momentum vector (which must have remained fixed in space). However, the finer structures of the apparent polar wander curves reveal 
anomalies to this first order interpretation, and suggest some relative movement between the different parts of Gondwanaland. Thus he thought that, while the development of the Palaeozoic crust had no doubt been affected by plate tectonics, the possibility that polar wander might also have played an important role should be considered. If so, was the timing of polar shifts related to that of periods of active plate movement?

Dr Briden agreed that the apparent polar wander paths for the different continents exhibited successive shifts and also excursions from quasi-stable positions. However, he argued that the shifts relative to Africa and Australia were not contemporaneous with those relative to Europe, and therefore interpreted the palaeomagnetic data entirely in terms of plate tectonics. He quoted, in particular, the Lower-Middle Devonian shift relative to Europe, and the pre-Silurian shift relative to Australia. Also he described a large Permo-Carboniferous shift for Africa and Australia not revealed in the European data. Discussion about the nature of these apparent polar shifts took place after the formal contributions.

Professor Runcorn suggested that polar wander might be related to the toroidal terms of the velocity field of convection currents in the mantle, whilst continental drift ('plate movements' in the current jargon) resulted from the poloidal terms. However, continental drift could only occur when the lithosphere was thin enough to be broken by the convection currents: in the Moon, for instance, the lithosphere is too thick to permit continental drift to occur, although he thought there was evidence which could be interpreted as showing that convection occurred within the body of the Moon. He also described results of palaeomagnetic measurements on lunar samples which indicate that the body of the Moon had shifted relative to the axis of rotation, i.e. he thought there had been polar wander on the Moon.

Professor Sutton considered the structural evidence relating to plate movements in the Pre-Cambrian and Palaeozoic. He pointed out the difficulties in comparing the lower-level orogenic structures of the Pre-Cambrian with the higher-level structures of today's mountain belts. However, he felt it was possible to put an age to the time when plates had come together by the dates of the intrusion of granites and of the ending of activity in the mobile belts. He considered that a good example of this is the South America and Africa junction, where granites of an early Cambrian age terminated the history of mobility and were followed by a final uplift after which there is no more evidence for compression. He suggested that the closing of the protoAtlantic between N. America and Europe ended around 400 My ago, but that between North America and Africa, compression persisted in the Appalachians until $200 \mathrm{My}$ ago. These plate junctions were 
later exploited by the Mesozoic phase of drift, now opening as opposed to closing. Sutton thus sees Mesozoic continental drift as part of a longer sequence of events: in particular in the Palaeozoic he sees evidence of a transition from a forming Pacific and a disappearing Atlantic to the present stage of a closing Pacific and an opening Atlantic.

Dr Vine reviewed the evidence from petrology which he felt pointed to considerable splitting and annealing of continents throughout geological history. Ophiolite, a basic suite of igneous rocks often associated with serpentinites and cherts, pointed to the sites of ancient Benioff zones. Also glaucophane schists marked these old regions of low temperature gradients. But why the lack of glaucophane schists in the Palaeozoic? Could this be due to the fact that here one is looking at a lower level of crust, with the calc-alkaline suites of metamorphic rocks being equivalent to the Benioff zones at depth. He endorsed Hess's original ideas on serpentinites being the most characteristic parts of these zones, and represented the first stages of mountain building and the closing of pre-existing oceans. Altogether there are indications of considerable suturing in the Palaeozoic.

Mr Harland showed how his group's work in the Arctic suggested a complicated relationship between Spitsbergen and Greenland, and proposed that any Lower Palaeozoic Atlantic Ocean was probably not as wide as at the present day. He considered that major transcurrent faulting had been active between North America and Europe after the closing of the proto-Atlantic, and thought this may be important when making Palaeozoic continental reconstructions. He also pointed out that the very rich fauna found in Spitsbergen suggested that it had been much nearer the equator, in good agreement with the palaeomagnetic evidence. In discussion, Spencer pointed out that the identity of the Late Pre-Cambrian and Lower Palaeozoic stratigraphical sequences on either side of the proto-Atlantic, and the location of the Grenville belt of metamorphism, both suggested a narrow ocean.

A lively discussion followed. It was opened by Mr B.J.J.Embleton and Dr D.Tarling who made short prepared contributions. Embleton spoke mainly about the Mid-Devonian polar shift relative to Europe. Its magnitude was $40^{\circ}$ and it must have occurred within less than $30 \mathrm{My}$ between 400 My BP (Lower Devonian Lavas) and 370 My (Norwegian dike). Briden pointed out that the Australian Mugga Mugga Porphyry had been dated radiometrically at $420 \mathrm{My}$, and that the polar shift relative to Australia had thus already occurred when it acquired its magnetization, i.e. before the European Mid-Devonian shift, which he argued must therefore have been a different event from the Australian. 
However, Creer pointed out that the cleaned remanent magnetization of Lower Devonian sediments from Bolivia and of Upper Devonian and Lower Carboniferous sediments from Brazil were consistent with the shift relative to Gondwana having occurred at the same time as the European. Thus there was some evidence of a Silurian-Lower Devonian-Upper Devonian polar excursion relative to Gondwanaland similar to that described by Briden for Europe. Discussion continued about the directions of these polar movements. The question will only be resolved beyond doubt if more measurements from radiometrically dated rocks for this time interval for the different continents can be obtained.

Tarling spoke mainly about the position of the pole relative to Gondwanaland and the Lower Palaeozoic, and said that in his opinion its movement during these periods could not yet be delineated: the poles for the different component landmasses and geological periods being too scattered.

The Permo-Carboniferous shift relative to Gondwanaland was also discussed. Creer, Embleton and Tarling agreed that the magnitude of this shift quoted by Briden was exaggerated. Even so it was still greater than the shift of the pole relative to Europe for this time.

Briden suggested the possibility of a persistent non-axial geomagnetic field in the Permo-Carboniferous period.

Sutton did not favour the rhythmic kind of drift inherent in Tuzo Wilson's ideas about the opening and losing of the N. Atlantic during the Palaeozoic. Marshall Kay and Dewey have argued that there may have been a primeval N. Atlantic up to about $500 \mathrm{~km}$ wide just before the onset of the Caledonian orogenic movements. But there seems no way of deducing from investigations of continental rocks how wide such a primeval ocean might have been before this.

Several other speakers contributed to the discussion which ended about 5.00 p.m. 